\title{
Incidental Diagnosis of Partial Anomalous
Pulmonary Venous Return: A Case Report
}

\author{
Parsiyel Pulmoner Venöz Dönüş Anomalisinin Tesadüfi Tanısı: \\ Olgu Sunumu
}

Ahmet Emre Hatır', Büşra Özyalvaç², Sevgi Pekcan², Necdet Poyraz ${ }^{3}$

\section{Abstract}

Partial anomalous pulmonary venous return is a rare congenital cardiac defect characterized by a flow of blood from a few of the pulmonary veins returning to the right atrium rather than the left atrium. Diagnosis of this anomaly can be quite difficult. The condition is usually diagnosed with echocardiography, and magnetic resonance imaging may also be useful. The clinical manifestation and progression of the disease varies depending on the amount of intra-cardiac shunt. Signs or symptoms may include dyspnea, coughing and fatigue. This defect usually causes no negative symptoms and the child can develop normally. This research presents the case on an 8-yearold female patient who complained of coughing and whose abnormal findings on a chest $X$-ray led to a further investigation. The patient was diagnosed with partial anomalous pulmonary venous return. Diagnosis of this anomaly at an early stage can lead to the patient gaining an awareness of the disease and being able to deal with any complications that arise in the adolescent period.

Key words: Partial anomalous pulmonary venous connection, Atrial septal defects, Magnetic Resonance lmaging.

\section{Özet}

Parsiyel anormal pulmoner venöz dönüş, pulmoner venlerin bir kaçının sol atriyum yerine sağ atriyuma geri dönmesi ile karakterize nadir görülen konjenital bir kardiyak defekttir. Bu anomalinin tanısını koymak oldukça zordur. Bu durum genellikle ekokardiyografi ile teşhis edilir, ayrıca manyetik rezonans görüntüsü de yararlı olabilir. Hastalığın klinik belirtisi ve seyri, intrakardiyak şantın miktarına bağlı olarak değişir. Belirti veya semptomlar; dispne, halsizlik ve öksürüğü içerebilir. Bu anomali genellikle ciddi semptomlara neden olmaz ve çocuk normal olarak büyür ve gelişir. Bu çalışmada akciğer grafisinde anormal bulguları olan ve öksürük şikayeti olan sekiz yaşında bir kız hasta sunulmuş ve ileri araştırma sonucunda parsiyel anormal pulmoner venöz dönüş tanısı konulmuştur. Bu hastalığın tanısının erken konulması, hastanın bu anomaliye olan farkındalığını artırarak ergenlik döneminde ortaya çıkabilecek komplikasyonlar ile baş etmesine olanak tanır.

Anahtar Sözcükler: Parsiyel anormal pulmoner venöz dönüş anomalisi, Atriyal septal defektler, Manyetik Rezonans Görüntüleme.
'Department of Family Medicine, Necmettin Erbakan University, Konya, Turkey

${ }^{2}$ Department of Pediatrics, Necmettin Erbakan University, Konya, Turkey

${ }^{3}$ Department of Radiology, Necmettin Erbakan University, Konya, Turkey
'Necmettin Erbakan Üniversitesi Meram Tıp Fakültesi, Aile Hekimliği Anabilim Dalı, Konya

${ }^{2}$ Necmettin Erbakan Üniversitesi Meram Tıp Fakültesi,

Çocuk Hastalıkları Anabilim Dalı, Konya

${ }^{3}$ Necmettin Erbakan Üniversitesi Meram Tıp Fakültesi, Radyoloji Anabilim Dalı, Konya

Submitted (Başvuru tarihi): 27.12.2019 Accepted (Kabul tarihi): 26.02.2020

Correspondence (iletişim): Ahmet Emre Hałır, Department of Family Medicine, Necmettin Erbakan University, Konya, Turkey

e-mail: hatiremre@gmail.com 
Partial anomalous pulmonary venous return (PAPVR) is a developmental disorder in which one or more pulmonary vein cannot connect to the left atrium. PAPVR is usually an acyanotic lesion (1), and while patients with this anomaly usually have an asymptomatic course during childhood, they may begin to show signs at an advanced age. This is due to volume overload, and leads to complaints such as fatigue, shortness of breath and coughing (2).

In this study, we present the case of an 8-year-old girl who was admitted to our hospital with fever and vomiting, and who had a previous history of hospitalization for pneumonia. The patient underwent further investigations after a suspicious lesion was identified on chest X-ray. As a result, partial anomalous pulmonary venous return was detected. We present this case report due to the spontaneous detection of PAPVR.

\section{CASE}

An 8-year-old female patient was brought to our hospital who, it was learned, complained of coughing, especially during the winter months, but that did not suffer severely and did not have frequent illnesses. There was no pathology related to birth, although there was a history of hospitalization due to a urinary tract infection at 6 months and pneumonia at 1 year of age. Her vaccines were completed. She had no known disease and had no regular medication. She had 2 healthy siblings and there was no kinship between her parents.

The height and weight percentiles were in the appropriate range. An examination of the oropharynx was normal, respiratory sounds were bilaterally equal and respiratory sounds were normal. No murmur was heard in the cardiovascular system.

There were no pathological features in laboratory tests. A computed tomography (CT) was carried out as a suspicious area was identified form the chest $X$-ray (Figure 1). The pulmonary veins located in the upper lobe of the left lung and the flow into the left brachiocephalic vein following the anterior aortic arch was reported (Figure 2). Left lateral upper partial abnormal pulmonary venous return was considered.

The patient consulted a pediatric cardiologist. An echocardiography (Echo) was performed and a small atrial septal defect (ASD) was detected, in addition to a partial pulmonary venous return anomaly. A $4 \mathrm{~mm}$ left-to-right shunt between the atria was observed. It was found that the vertical vein collecting the flow originating from the upper zone of the left lung was entering the innominate vein. There was also mild insufficiency in the tricuspid valve (4th degree). As a result of these findings and clinical picture, the patient was not planned to be operated on by the pediatric cardiologist, and medical follow-up was recommended.

\section{DISCUSSION}

PAPVR was first described by Winslow in 1739 (3). When an ASD is detected on an Echo, it is always necessary to look for an associated PAPVR. It is difficult to differentiate the symptoms, signs, electrocardiographic and radiological findings of isolated ostium secundum ASD findings. An Echo usually confirms the diagnosis. PAPVR is rare, and has a good prognosis, similar to ostium secundum ASD (1). PAPVR is examined in five different types, with the type that connects to the superior vena cava (SVC) being the most common. Abnormal pulmonary veins connect to the lower side of the SVC or SVC-right atrial junction in the most common type. Anomalies are frequently seen with sinus venosus-atrial septal defects (4). Our case had the most common type of PAPVR, and a small ASD was detected. In a retrospective multi-slice computer tomography (MSCT) study performed by Ho et al. (5), PAPVR anomalies were encountered at a rate of $0.1 \%$ in 45,538 live cases.

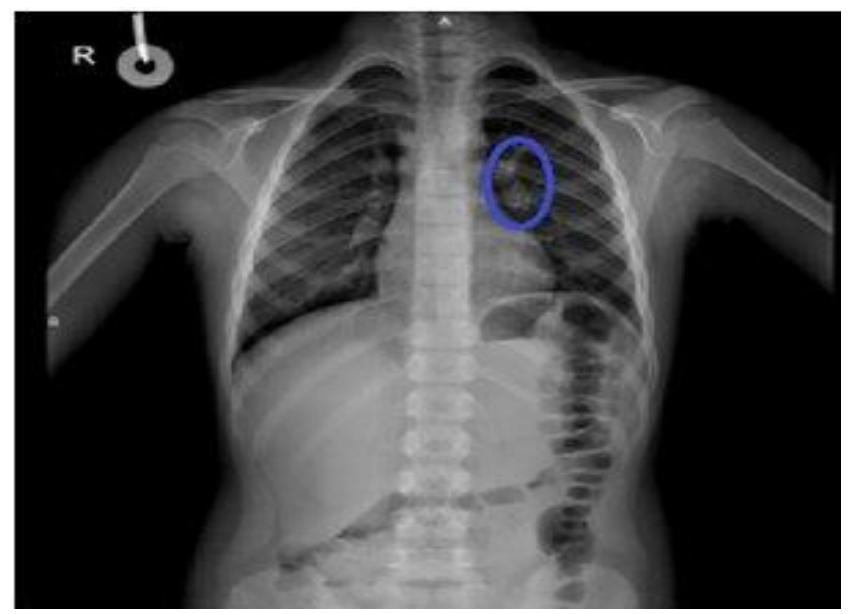

Figure 1: The suspicious area indicated in blue is remarkable on the Posterior-Anterior Chest X-ray
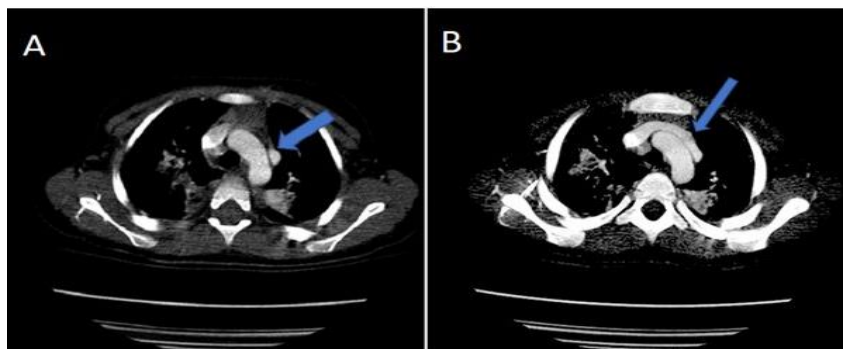

Figure 2: Axial MSCT images show that the left superior pulmonary vein indicated by the blue arrow in $A$, opens into the left brachiocephalic vein at the point indicated by the blue arrow in $B$ 
linical findings may vary in the left-to-right shunt ratio, in the number and localization of abnormal veins, in the presence of possible complications such as infection, in the accompaniment of ASD, and in the size of such ASDs. If the volume of the shunt is high, secondary pulmonary hypertension may develop. Cases in which less than half of the lung volume join the systemic circulation are asymptomatic $(6,7)$. Common signs and symptoms may include dyspnea, coughing, fatigue, chest pain, palpitations and tachycardia (5). Heart murmurs and arrhythmias are also likely. In contrast to PAPVR, patients with scimitar syndrome are more likely to develop symptoms at an early age and are more likely to have cyanosis (8).

The radiographical diagnosis of PAPVR is very difficult. If PAPVR is accompanied by hypogenetic lung syndrome, radiography plays an important role in the diagnosis (9). Chest radiography is usually the first imaging method. Radiographic findings depend on abnormal drainage, the affected lobe and the left to right shunt. A chest X-ray may be normal, or dilated SVC, cardiomegaly, right ventricular dilatation, right atrial dilatation, pulmonary edema or right ventricular dilatation may be seen (10).

If a significant left-to-right shunt is identified in Echo, there is a paradoxical interventricular septal movement, and a right ventricular volume overload may develop. Abnormal venous drainage to the right SVC may be more difficult to detect unless a systematic approach is performed. Surgical interventions should be considered in cases with a volume-loaded right ventricle. Surgery is not necessary when a single abnormally drained vein does not load the right ventricle volume. Surgery is typically performed at a similar time to ASD repair, when the patient is 3-5 years of age. The type of surgery depends on the location of the drainage, but generally involves reconnecting the abnormal vessels directly to the left. Patients with a repaired PAPVR have good prognosis (11).

In our case, minimal ASDs were seen in Echo. The patient had no common symptom or infection, and so no cardiologic operation was planned, with follow-up recommended instead. In this study, we conclude that a chest X-ray taken as the first approach, together with the patient's clinic and history, provided us with important clues. Our patient had a history of hospitalization due to pneumonia, coughing especially in winter, and a suspicious area on a chest radiography, leading to further investigations.

\section{CONCLUSION}

Patients can cope with the complications that may arise in the adolescent period and at a more advanced age because of the diagnosis of partial anomalous pulmonary venous return and patients also may be under control. We can also learn that knowing the cause of the symptoms of the disease can prevent the patient from applying to the hospital continuously and unnecessary hospitalization can be prevented.

\section{CONFLICTS OF INTEREST}

None declared.

\section{AUTHOR CONTRIBUTIONS}

Concept - A.E.H., B.Ö., S.P., N.P.; Planning and Design - A.E.H., B.Ö., S.P., N.P.; Supervision - A.E.H., B.Ö., S.P. N.P.; Funding - S.P., N.P.; Materials - S.P.; Data Collection and/or Processing - S.P., A.E.H.; Analysis and/or Interpretation - S.P., N.P., A.E.H., B.Ö.; Literature Review - A.E.H., S.P., B.Ö.; Writing - A.E.H., S.P., B.Ö.; Critical Review - S.P.

\section{YAZAR KATKILARI}

Fikir - A.E.H., B.Ö., S.P., N.P.; Tasarım ve Dizayn A.E.H., B.Ö., S.P., N.P.; Denetleme - A.E.H., B.Ö., S.P., N.P.; Kaynaklar - S.P., N.P.; Malzemeler - S.P.; Veri Toplama ve/veya İşleme - S.P., A.E.H.; Analiz ve/veya Yorum - S.P., N.P., A.E.H., B.Ö.; Literatür Taraması - A.E.H., S.P., B.Ö.; Yazıyı Yazan - A.E.H., S.P., B.Ö.; Eleştirel Inceleme - S.P.

\section{REFERENCES}

1. Bernstein D. Partial anomalous pulmonary venous return. In: Kliegman RM, St. Geme JW, Blum NJ et al, eds. Nelson textbook of pediatrics. 21th edition. Elsevier; 2019:2376.

2. Yüksekkaya R, Çelikyay F, Yılmaz A, Deniz Ç, Gökçe E. Parsiyel anormal pulmoner venöz dönüş anomalisinin çok kesitli bilgisayarlı tomografi anjiografi bulguları: iki olgunun sunumu. Dicle Med J 2013; 40:128-30. [CrossRef]

3. Winslow J. Mem Acad Roy Sci 1739:113.

4. Kirklin JW, Barrett-Boyes BG. Atrial septal defect and partial anomalous pulmonary venous connection. Cardiac surgery. 2nd edition, Vol 1. New York, NY: Churchill Livingstone 1993; 1:627-30.

5. Ho LM, Bhalla S, Bierhals A, Gutierrez F. MDCT of partial anomalous pulmonary venous return (PAPVR) in adults. J Thoracic Imaging 2009; 24:89-95. [CrossRef] 
6. Miller S, Waltman A. The pulmonary circulation. In: Tavares JM, Ferrucci JT eds. Radiology: DiagnosisImaging Intervention. Philedelphia: JB Lippincott; 1995; 1-19.

7. Miller S, Waltman A. The pulmonary circulation. In: Tavares JM, Ferrucci JT eds. Radiology: DiagnosisImaging Intervention. Philedelphia: JB Lippincott; 1995; 1-19. [CrossRef]

8. Vyas HV, Greenberg SB, Krishnamurthy R. MR imaging and $\mathrm{CT}$ evaluation of congenital pulmonary vein abnormalities in neonates and infants. Radiographics 2011; 32:87-98. [CrossRef]
9. Neill CA, Ferencz C, Sabiston DC, Sheldon H. The familial occurrence of hypoplastic right hung with systemic arterial supply and venous drainage "Scimitar syndrome". Bull Johns Hopkins Hosp 1960; 107:1-21.

10. Katre R, Burns SK, Murillo H, Lane MJ, Restrepo CS. Anomalous pulmonary venous connections. Semin Ultrasound CT MR 2012; 33:485-99. [CrossRef]

11. Webb GD, Smallhorn JF, Therrien J, Redington AN. Congenital heart diseases. In: Bonow RO, Mann DL, Zipes DP, Libby P eds. Braunwald's heart disease: a textbook of cardiovascular medicine. 9th edition. Philadelphia: Elsevier Saunders; 2011 :1464-5. 